\title{
An Evaluation of the Genetic Diversity of Xylella fastidiosa Isolated from Diseased Citrus and Coffee in São Paulo, Brazil
}

\author{
Xiaoting Qin, Vicente S. Miranda, Marcos A. Machado, Eliana G. M. Lemos, and John S. Hartung
}

First and fifth authors: USDA-ARS Fruit Laboratory, 10300 Baltimore Ave., Beltsville, MD 20705; second author: FundeCitrus Av. Dr. Adhemar Pereira de Barros, 14807-040 Araraquara, SP, Brazil; third author: Centro de Citricultura Sylvio Moreira, Cordeiropolis, SP, Brazil; and fourth author: Universidade Estadual Paulista, Jaboticabal, SP, Brazil.

Accepted for publication 12 March 2001.

\section{ABSTRACT}

Qin, X., Miranda, V. S., Machado, M. A., Lemos, E. G. M., and Hartung, J. S. 2001. An evaluation of the genetic diversity of Xylella fastidiosa isolated from diseased citrus and coffee in São Paulo, Brazil. Phytopathology 91:599-605.

Strains of Xylella fastidiosa, isolated from sweet orange trees (Citrus sinensis) and coffee trees (Coffea arabica) with symptoms of citrus variegated chlorosis and Requeima do Café, respectively, were indistinguishable based on repetitive extragenic palindromic polymerase chain reaction (PCR) and enterobacterial repetitive intergenic consensus PCR assays. These strains were also indistinguishable with a previously described PCR assay that distinguished the citrus strains from all other strains of Xylella fastidiosa. Because we were not able to document any genomic diversity in our collection of Xylella fastidiosa strains isolated from diseased citrus, the observed gradient of increasing disease severity from southern to northern regions of São Paulo State is unlikely due to the presence of significantly different strains of the pathogen in the different regions. When comparisons were made to reference strains of Xylella fastidiosa isolated from other hosts using these methods, four groups were consistently identified consistent with the hosts and regions from which the strains originated: citrus and coffee, grapevine and almond, mulberry, and elm, plum, and oak. Independent results from random amplified polymorphic DNA (RAPD) PCR assays were also consistent with these results; however, two of the primers tested in RAPD-PCR were able to distinguish the coffee and citrus strains. Sequence comparisons of a PCR product amplified from all strains of Xylella fastidiosa confirmed the presence of a $C f o \mathrm{I}$ polymorphism that can be used to distinguish the citrus strains from all others. The ability to distinguish Xylella fastidiosa strains from citrus and coffee with a PCR-based assay will be useful in epidemiological and etiological studies of this pathogen.
Xylella fastidiosa Wells et al., was originally described as the causal agent of Pierce's disease of grapevine and as a pathogen of plum, peach, and numerous urban shade trees in the United States $(15,24,30)$. The gram-negative bacterium has characteristically rippled cell walls and is found in nature only in the xylem of infected plants (19) or in the mouth parts and cibarial pump organ of sharpshooter leafhopper vectors (family Cicadelinidae) $(2,23)$. Xylella fastidiosa grows slowly in vitro, requiring somewhat specialized microbiological media, and initially was very difficult to culture (10). Xylella fastidiosa was known only in North America until 1987 when a serious new disease of sweet orange (Citrus sinensis [L.] Osb) was described in São Paulo State, Brazil. Symptoms on sweet orange include bright yellow leaf mottle with distinct lesions on the adaxial leaf surface. In older leaves, these lesions extend through the leaf to form gummy blisterlike lesions on the abaxial leaf surface. Internodes on severely affected plants are markedly shortened, and leaves are abnormally small. Fruit fail to fill and remain small and hard at harvest time. Electron microscopy of infected trees showed bacterial occlusions in the xylem vessels $(3,28)$, and Xylella fastidiosa was isolated from infected plants. Koch's postulates have been completed for the disease, termed citrus variegated chlorosis (CVC) $(4,14)$.

Thirty-five percent of the 200 million sweet orange trees in São Paulo State showed symptoms of CVC disease in 1999 and 2000 seasons, and disease incidence and severity are increasing (1).

Corresponding author: J. S. Hartung; E-mail address: Hartungj@ba.ars.usda.gov

Publication no. P-2001-0420-01R

This article is in the public domain and not copyrightable. It may be freely reprinted with customary crediting of the source. The American Phytopathological Society, 2001.
This disease is a major impediment to citriculture in Brazil. If citrus trees are valued at $\$ 15$ U.S. currency each, as is the case in Brazil for insurance purposes, then the destruction of trees already symptomatic with CVC represents a direct loss of more than 1 billion U.S. dollars. Fortunately, CVC has not been reported elsewhere in the world, except for areas of Argentina immediately adjacent to Brazil. It is however, viewed as a threat to U.S. citriculture (26).

We showed previously, based on random amplified polymorphic DNA polymerase chain reaction (RAPD-PCR) analysis of the limited number of citrus strains then available, that Xylella fastidiosa from citrus was genetically quite distinct from the previously described North American strains (20). Since that time, we have assembled a large collection of strains from affected citrus. In addition, data now available show that different production regions within São Paulo State report different rates of trees showing symptoms, ranging from 16 to $53 \%$, and these regions also report different losses of yield, ranging from 1 to $40 \%$. It may be that different strains of the pathogen are present in different production regions and that this is the explanation for the observed differences in disease incidence and severity. More recently, coffee leaf scorch or Requiema do Café was found in coffee (Coffea arabica L.) plantations in São Paulo State and shown to be caused by Xylella fastidiosa (12). Because the coffee and citrus production areas of São Paulo State are largely congruent, the relationship, if any, between the coffee and citrus strains is an urgent research question. The objectives of this research were, therefore, to (i) determine if differences in genome structure within the collection of strains isolated from citrus could be correlated with variations in symptom severity observed in affected groves; (ii) determine if there were differences in genome structure between strains of Xylella fastidiosa collected from citrus in various regions of São Paulo State and from coffee plants in the same 
region; and (iii) develop a rapid test to distinguish between strains isolated from citrus and coffee. For these purposes, we have used several techniques based on the PCR, including repetitive extragenic palindromic (REP) PCR and enterobacterial repetitive intergenic consensus (ERIC) PCR $(11,29)$ as well as RAPD-PCR (31) and PCR-restriction fragment length polymorphism (RFLP) analyses.

\section{MATERIALS AND METHODS}

Bacterial strains and DNA isolation. Citrus and coffee strains of Xylella fastidiosa were isolated in Beltsville, MD, from leaf samples collected in São Paulo, Brazil, and at Fundecitrus, Araraquara, São Paulo. Leaves were washed under running tap water and soaked in $0.5 \%$ sodium hypochlorite for 3 min followed by three rinses in sterile distilled water. Leaf petioles and midribs were excised and the ends removed, and the fresh petiole/ midrib was pressed onto supplemented periwinkle wilt (SPW) media (14) or the petioles were sliced into SPW broth in culture tubes. Cultures were incubated at $27^{\circ} \mathrm{C}$ and observed for signs of microbial growth. Any bacterial growth that appeared before 5 days was considered contamination. Colonies of Xylella fastidiosa were visible after 2 weeks or sometimes longer on plates. Serial cultures were made, and single colonies were isolated three times prior to the experimental work. Strains with an ATCC prefix are from the American Type Culture Collection, Manassas, VA. Other reference strains were kindly provided by colleagues in the United States.

DNA was isolated with genomic DNA isolation kits from Qiagen (Chatsworth, CA) according to the protocol provided by the manufacturer for blood cells.

REP-PCR analyses. Reactions were performed in a final volume of $25 \mu \mathrm{l}$ with an automated thermal cycler (Perkin-Elmer, Wellesley, MA). The (10X) reaction buffer consisted of $160 \mathrm{mM}\left(\mathrm{NH}_{4}\right)_{2} \mathrm{SO}_{4}$, $670 \mathrm{mM}$ Tris- $\mathrm{HCl}\left(\mathrm{pH} 8.8\right.$ at $\left.25^{\circ} \mathrm{C}\right)$, and $0.1 \%$ Tween 20 detergent. Each reaction mixture contained $2.5 \mu$ of $10 \times$ buffer; $1.25 \mu \mathrm{l}$ of $50 \mathrm{mM} \mathrm{MgCl} 2$ (2.5 mM Mg${ }^{++}$final); $7.0 \mu \mathrm{l}$ of dNTP mix, each at $1.25 \mathrm{mM}(0.35 \mathrm{mM}$ each nucleotide final $) ; 2 \mu \mathrm{l}$ of template DNA at $1 \mu \mathrm{g} / \mathrm{ml}$ (20 ng per reaction); and $10.05 \mu \mathrm{l}$ of water. For REP-PCR, $1 \mu \mathrm{l}$ of primers REP1R-1 and REP2-1 (11) each at $0.05 \mathrm{mmol} / \mathrm{ml}(0.02 \mathrm{mM}$ final $)$ and 1 unit of Taq polymerase (Biolase, Intermountain Scientific, Salt Lake City, UT) were added. Amplification was carried out at $94^{\circ} \mathrm{C}$ for $1 \mathrm{~min}, 42^{\circ} \mathrm{C}$ for $1 \mathrm{~min}$, and $72^{\circ} \mathrm{C}$ for $1 \mathrm{~min}$ for 30 cycles followed by a single final extension cycle of $72^{\circ} \mathrm{C}$ for $5 \mathrm{~min}$. Amplification products were stored at $4^{\circ} \mathrm{C}$ prior to electrophoresis through a $2 \%$ agarose gel. Amplification products were visualized with UV light after staining with $0.5 \%$ ethidium bromide.

ERIC-PCR analyses. Reaction mixtures were prepared the same as the REP-PCR reactions, except that the primers used

TABLE 1. Strains of Xylella fastidiosa used in the polymerase chain reaction (PCR) analyses of this study

\begin{tabular}{|c|c|c|c|c|c|c|c|c|}
\hline \multirow[b]{2}{*}{ Designation } & \multirow[b]{2}{*}{ Host } & \multirow[b]{2}{*}{ Symptoms } & \multirow[b]{2}{*}{ Location } & \multicolumn{5}{|c|}{ Patterns observed after ${ }^{\mathrm{a}}$} \\
\hline & & & & REP & ERIC & CfoI & AO9 & NO4 \\
\hline Col-1 & Sweet Orange & Unknown & Colima & 1 & 1 & 1 & 1 & 1 \\
\hline Col-3 & Sweet Orange & Unknown & Colima & 1 & 1 & 1 & 1 & 1 \\
\hline Col-7 & Sweet Orange & Mild & Colima & 1 & 1 & 1 & 1 & 1 \\
\hline Col-11 & Sweet Orange & Unknown & Colima & 1 & 1 & 1 & 1 & 1 \\
\hline Taq 12 & Sweet Orange & Severe & Taquaratinga & 1 & 1 & 1 & 1 & 1 \\
\hline Taq 2-10 & Sweet Orange & Severe & Taquaratinga & 1 & 1 & 1 & 1 & 1 \\
\hline Taq 33 & Sweet Orange & Severe & Taquaratinga & 1 & 1 & 1 & 1 & 1 \\
\hline Taq 29 & Sweet Orange & Severe & Taquaratinga & 1 & 1 & 1 & 1 & 1 \\
\hline Taq 30 & Sweet Orange & Severe & Taquaratinga & 1 & 1 & 1 & 1 & 1 \\
\hline Taq 43-10 & Sweet Orange & Severe & Taquaratinga & 1 & 1 & 1 & 1 & 1 \\
\hline BB 1 & Sweet Orange & Severe & Bebedouro & 1 & 1 & 1 & 1 & 1 \\
\hline BB 2 & Sweet Orange & Severe & Bebedouro & 1 & 1 & 1 & 1 & 1 \\
\hline BB 3 & Sweet Orange & Severe & Bebedouro & 1 & 1 & 1 & 1 & 1 \\
\hline BB 4 & Sweet Orange & Severe & Bebedouro & 1 & 1 & 1 & 1 & 1 \\
\hline BB 6 & Sweet Orange & Severe & Bebedouro & 1 & 1 & 1 & 1 & 1 \\
\hline BB 7 & Sweet Orange & Severe & Bebedouro & 1 & 1 & 1 & 1 & 1 \\
\hline BB 8 & Sweet Orange & Severe & Bebedouro & 1 & 1 & 1 & 1 & 1 \\
\hline $2 \mathrm{AB}$ & Sweet Orange & Mild & Bebedouro & 1 & 1 & 1 & 1 & 1 \\
\hline $4 \mathrm{AB}$ & Sweet Orange & Mild & Bebedouro & 1 & 1 & 1 & 1 & 1 \\
\hline $5 \mathrm{AB}$ & Sweet Orange & Mild & Bebedouro & 1 & 1 & 1 & 1 & 1 \\
\hline $2 \mathrm{BB}$ & Sweet Orange & Severe & Bebedouro & 1 & 1 & 1 & 1 & 1 \\
\hline F-1 & Sweet Orange & Mild & Bebedouro & 1 & 1 & 1 & 1 & 1 \\
\hline $\mathrm{F}-2$ & Sweet Orange & Severe & Bebedouro & 1 & 1 & 1 & 1 & 1 \\
\hline F-5 & Sweet Orange & Mild & Bebedouro & 1 & 1 & 1 & 1 & 1 \\
\hline $3 \mathrm{BA}$ & Sweet Orange & Severe & Araraquara & 1 & 1 & 1 & 1 & 1 \\
\hline $4 \mathrm{AA}$ & Sweet Orange & Mild & Araras & 1 & 1 & 1 & 1 & 1 \\
\hline A 2 & Sweet Orange & Mild & Araraquara & 1 & 1 & 1 & 1 & 1 \\
\hline A 3 & Sweet Orange & Mild & Araraquara & 1 & 1 & 1 & 1 & 1 \\
\hline A 4 & Sweet Orange & Mild & Araraquara & 1 & 1 & 1 & 1 & 1 \\
\hline A 5 & Sweet Orange & Mild & Araraquara & 1 & 1 & 1 & 1 & 1 \\
\hline A 9 & Sweet Orange & Mild & Araraquara & 1 & 1 & 1 & 1 & 1 \\
\hline A 12 & Sweet Orange & Mild & Araraquara & 1 & 1 & 1 & 1 & 1 \\
\hline Funde-3 & Sweet Orange & Unknown & São Paulo & 1 & 1 & 1 & 1 & 1 \\
\hline Funde-5 & Sweet Orange & Unknown & São Paulo & 1 & 1 & 1 & 1 & 1 \\
\hline CVC 94-2 & Sweet Orange & Severe & São Paulo & 1 & 1 & 1 & 1 & 1 \\
\hline CVC 94-1 & Sweet Orange & Severe & São Paulo & 1 & 1 & 1 & 1 & 1 \\
\hline
\end{tabular}

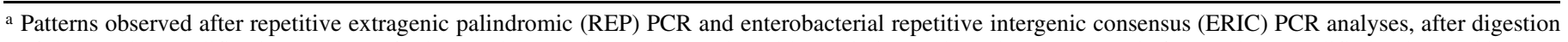
of the 472-bp amplification product of primer pair 272-1-int and 272-2-int with restriction endonuclease CfoI, and after random amplified polymorphic DNA (RAPD) PCR analyses of the set of strains with primers AO9 and NO4. Strains that share a common pattern designation number have indistinguishable patterns of amplification products after PCR or PCR restriction fragment length polymorphism (RFLP) and agarose gel electrophoresis. Strains that have different pattern designation numbers have different patterns of amplification products. 
were ERIC-1R and ERIC-2 (11) and 0.5 units of Taq polymerase were used with 0.5 units of Platinum Taq (Life Technologies, Grand Island, NY). Amplification was carried out at $94^{\circ} \mathrm{C}$ for $1 \mathrm{~min}, 52^{\circ} \mathrm{C}$ for $1 \mathrm{~min}$, and $72^{\circ} \mathrm{C}$ for $1 \mathrm{~min}$ for 30 cycles followed by a single final extension cycle of $72^{\circ} \mathrm{C}$ for $5 \mathrm{~min}$. Amplification products were stored at $4{ }^{\circ} \mathrm{C}$ prior to electrophoresis through a $2 \%$ agarose gel. Amplification products were visualized with UV light after staining with $0.5 \%$ ethidium bromide.

RAPD-PCR analyses. Six primers were used for RAPD-PCR assays. Amplification reactions and conditions were the same as described for REP-PCR, except only one primer was used per reaction and the volume of water used was $11.05 \mu \mathrm{l}$. The primers used were A09 (5'-GGGTAACGCC), N04 (5'-GACCGACCCA), G19 (5'-GTCAGGGCAA), G10 (5'-AGGGCCGTCT), H03 (5'AGACGTCCAC), and H12 (5'-ACGCGCATGT). Amplification products were stored at $4{ }^{\circ} \mathrm{C}$ prior to electrophoresis through a $2 \%$ agarose gel. Amplification products were visualized with UV light after staining with $0.5 \%$ ethidium bromide.

PCR-RFLP and DNA sequencing. The reaction mixtures for PCR amplification under stringent conditions were the same as those described for REP-PCR, except primer pair 272-1-int and 272-2-int was used (21). Amplification was carried out at $94^{\circ} \mathrm{C}$ for $1 \mathrm{~min}, 67^{\circ} \mathrm{C}$ for $1 \mathrm{~min}$, and $72^{\circ} \mathrm{C}$ for $1 \mathrm{~min}$ for 30 cycles followed by a single extension cycle of $72^{\circ} \mathrm{C}$ for $5 \mathrm{~min}$. Amplification products were stored at $4{ }^{\circ} \mathrm{C}$ prior to electrophoresis through a $2 \%$ agarose gel, and were visualized with UV light after staining with
$0.5 \%$ ethidium bromide. Aliquots of the amplification reactions were separately digested with 5 units of restriction endonucleases MspI, HaeIII, RseI, and CfoI. Digestion products were visualized by ethidium bromide staining after electrophoresis through $4 \%$ agarose gels.

Based on the results of the PCR assays described previously, the amplification products of primer pair 272-1-int and 272-2-int from coffee and citrus strains were cloned into plasmid pCR2.1 with the TA cloning kit (Invitrogen, Carlsbad, CA). The nucleotide sequence of the amplification products was determined by the Interdisciplinary Center for Biotechnology Research of the University of Florida, Gainesville. Sequence alignments and comparisons were made using the MacVector 5.0 program (Kodak, Rochester, NY). These sequences have been deposited as GenBank Accessions Nos. AF344190 and AF344191.

Calculation of a similarity matrix and dendrogram. Because polymorphisms were not observed within groups of strains isolated from several of the hosts, strains ATCC 35868 (mulberry), ATCC 35870 (almond), ATCC 35873 (American elm), Fund-4 (coffee), and $\mathrm{Col} 7$ (orange) were used as representative strains from their respective hosts. Fifty-two discrete amplification products were identified as present or absent in agarose gels after REP-, ERIC-, and RAPD-PCR using these strains. A similarity matrix and dendrogram were calculated using NTSYSpc (Applied Biostatistics Inc., Setauket, NY) and the SAHN and unweighted pair-group method algorithms.

TABLE 1. (continued from preceding page)

\begin{tabular}{|c|c|c|c|c|c|c|c|c|}
\hline \multirow[b]{2}{*}{ Designation } & \multirow[b]{2}{*}{ Host } & \multirow[b]{2}{*}{ Symptoms } & \multirow[b]{2}{*}{ Location } & \multicolumn{5}{|c|}{ Patterns observed after ${ }^{\mathrm{a}}$} \\
\hline & & & & REP & ERIC & CfoI & AO9 & $\mathrm{NO} 4$ \\
\hline CVC 93-1-R & Sweet Orange & Severe & São Paulo & 1 & 1 & 1 & 1 & 1 \\
\hline CVC 93-2 & Sweet Orange & Severe & São Paulo & 1 & 1 & 1 & 1 & 1 \\
\hline LAR 20/11 & Sweet Orange & Unknown & São Paulo & 1 & 1 & 1 & 1 & 1 \\
\hline H-1 & Sweet Orange & Mild & Itapetininga & 1 & 1 & 1 & 1 & 1 \\
\hline H-5 & Sweet Orange & Mild & Itapetininga & 1 & 1 & 1 & 1 & 1 \\
\hline H-6 & Sweet Orange & Severe & Itapetininga & 1 & 1 & 1 & 1 & 1 \\
\hline $\mathrm{H}-7$ & Sweet Orange & Mild & Itapetininga & 1 & 1 & 1 & 1 & 1 \\
\hline H-8 & Sweet Orange & Severe & Itapetininga & 1 & 1 & 1 & 1 & 1 \\
\hline C-1 & Sweet Orange & Mild & Olimpia & 1 & 1 & 1 & 1 & 1 \\
\hline C-10 & Sweet Orange & Unknown & Olimpia & 1 & 1 & 1 & 1 & 1 \\
\hline $1-B$ & Sweet Orange & Severe & José Benefacio & 1 & 1 & 1 & 1 & 1 \\
\hline $3-B$ & Sweet Orange & Severe & José Benefacio & 1 & 1 & 1 & 1 & 1 \\
\hline $6-B$ & Sweet Orange & Severe & Jales & 1 & 1 & 1 & 1 & 1 \\
\hline 8-B & Sweet Orange & Severe & Jales & 1 & 1 & 1 & 1 & 1 \\
\hline $9-B$ & Sweet Orange & Severe & Jales & 1 & 1 & 1 & 1 & 1 \\
\hline $1-\mathrm{A}$ & Sweet Orange & Mild & Jales & 1 & 1 & 1 & 1 & 1 \\
\hline CVC-L1 & Sweet Orange & Unknown & São Paulo & 1 & 1 & 1 & 1 & 1 \\
\hline CVC-L2 & Sweet Orange & Unknown & São Paulo & 1 & 1 & 1 & 1 & 1 \\
\hline CVC-5 & Sweet Orange & Unknown & São Paulo & 1 & 1 & 1 & 1 & 1 \\
\hline CVC 12-1 & Sweet Orange & Unknown & São Paulo & 1 & 1 & 1 & 1 & 1 \\
\hline PW & Sweet Orange & Unknown & São Paulo & 1 & 1 & 1 & 1 & 1 \\
\hline Funde-4 & Coffee & Scorch & Casa Branca & 1 & 1 & 2 & 2 & 2 \\
\hline Café 20/11 & Coffee & Scorch & São Paulo & 1 & 1 & 2 & 2 & 2 \\
\hline RP-1 & Coffee & Scorch & Rio Preto & 1 & 1 & 2 & 2 & 2 \\
\hline M-1 & Coffee & Scorch & Marilia & 1 & 1 & 2 & 2 & 2 \\
\hline $\mathrm{F}-1$ & Coffee & Scorch & Franca & 1 & 1 & 2 & 2 & 2 \\
\hline ATCC 35870 & Almond & Scorch & California & 2 & 2 & 2 & 3 & 3 \\
\hline ALS-BCG & Almond & Scorch & California & 2 & 2 & 2 & 3 & 3 \\
\hline ATCC 35876 & Ragweed & Stunt & Florida & 2 & 2 & 2 & 3 & 3 \\
\hline ATCC 35877 & Grapevine & Scorch & California & 2 & 2 & 2 & 3 & 3 \\
\hline ATCC 35879 & Grapevine & Scorch & Florida & 2 & 2 & 2 & 3 & 3 \\
\hline ATCC 35881 & Grapevine & Scorch & Florida & 2 & 2 & 2 & 3 & 3 \\
\hline PCE-FG & Grapevine & Scorch & Unknown & 2 & 2 & 2 & 3 & 3 \\
\hline ATCC 35868 & Mulberry & Scorch & Massachusetts & 3 & 3 & 2 & 4 & 4 \\
\hline ATCC 35869 & Mulberry & Scorch & Massachusetts & 3 & 3 & 2 & 4 & 4 \\
\hline MUL-R & Mulberry & Scorch & Unknown & 3 & 3 & 2 & 4 & 4 \\
\hline MUL-1 & Mulberry & Scorch & Unknown & 3 & 3 & 2 & 4 & 4 \\
\hline Elm-1 & Elm & Scorch & $\ldots$ & 4 & 4 & 2 & 5 & 5 \\
\hline Elm-J208 & Elm & Scorch & $\ldots$ & 4 & 4 & 2 & 5 & 5 \\
\hline ATCC 35873 & Elm & Scorch & Washington, D.C. & 4 & 4 & 2 & 5 & 5 \\
\hline ATCC 35871 & Plum & Scorch & Georgia & 4 & 4 & 2 & 5 & 5 \\
\hline ATCC 35874 & Oak & Scorch & Georgia & 4 & 4 & 2 & 5 & 5 \\
\hline
\end{tabular}




\section{RESULTS}

Fifty-seven strains of Xylella fastidiosa isolated from diseased citrus over a period of 5 years from all regions of São Paulo State, where CVC disease occurs, were used in this study. Representative results for the ERIC-PCR analysis of the citrus strains are shown in Figure 1. All other citrus strains tested gave fingerprints that were indistinguishable from these after ERIC-PCR (Table 1). The five coffee strains also shared this fingerprint (Fig. 1). The results of REP-PCR (Table 1) on the set of citrus and coffee strains exactly paralleled the ERIC-PCR results. Polymorphisms between strains isolated from coffee and citrus and strains isolated from other hosts were easily observed after both ERIC-PCR and REP-PCR (Fig. 1; Table 1). Four clear groups of strains were identified: the citrus/ coffee group; a second group composed of strains from grapevine, almond, and ragweed; a third group composed of strains from mulberry; and a fourth group composed of strains from elm, oak, and plum from North America. The strains were resolved into the same four groups by both REP- and ERIC-PCR (Fig. 1; Table 1).

Six 10-mer oligonucleotide primers were used to perform RAPDPCR on the collection of strains (Table 1). All six primers re-

A
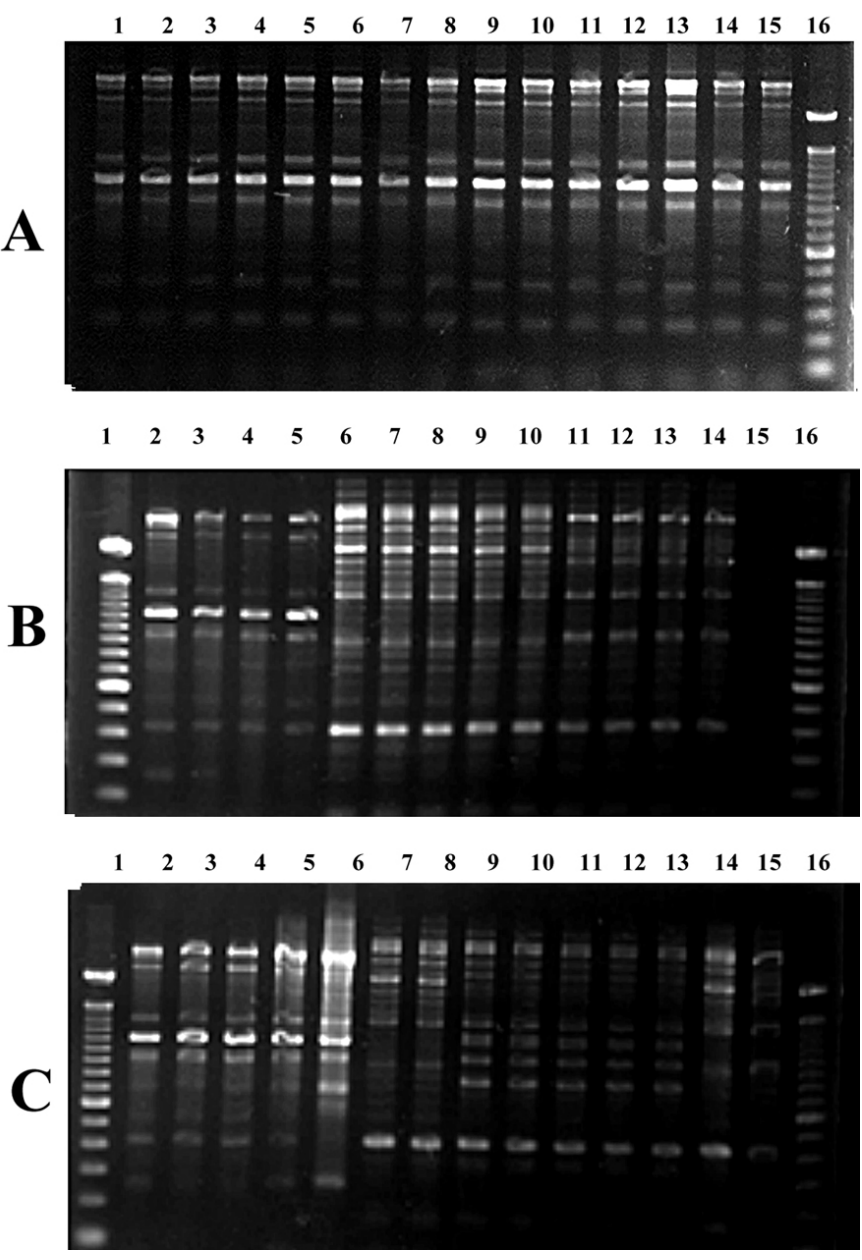

Fig. 1. Patterns produced by representative strains of Xylella fastidiosa after enterobacterial repetitive intergenic consensus polymerase chain reaction. $\mathbf{A}$, Lanes 1 to 15, citrus strains A4, A3, A2, 4AA, 3BA, BB7, F-1, F-2, 4AB, 2BB, 2AB, F-5, BB1, BB8, and 5AB; and lane 16, 100-bp ladder. B, Lanes 2 to 14, strains CVC-5 and Funde-5 (citrus), Funde-4, Café 20/11 (coffee), ATCC 35881, ATCC 35879, ATCC 35877 (grapevine), ATCC 35876 (ragweed), ATCC 35870 (almond), MUL-1, MUL-R, ATCC 35869, and ATCC 35868 (mulberry); and lanes 1 and 16, 100-bp ladder. C, Lanes 2 to 6, strains F-5, B-9, 3-B, CVC-L1, and PW (citrus); lanes 7 to 15, strains PCE-FG (grapevine), ALS.BCG (almond), ATCC 35873 (elm), ATCC 35874 (oak), ATCC 35871 (plum), ELM J208 and ELM-1 (elm), ATCC 35870 (almond), and ATCC 35868 (mulberry); and lanes 1 and 16, 100-bp ladder. vealed polymorphisms between the citrus/coffee group of strains and the other strains tested. However, only primer pairs AO9 and NO4 were able to reveal polymorphisms between the citrus and coffee strains (Fig. 2). None of the six primers revealed polymorphisms among any of the 57 strains isolated from diseased citrus (Fig. 2; Table 1). The Xylella fastidiosa strains were sorted into the same groups by RAPD-PCR as with the REP- and ERIC-PCR assays (Fig. 2).

The similarity matrix and dendrogram revealed a very deep division $(S=0.45)$ between the strains from coffee and citrus and those from all other hosts (Fig. 3). Among the strains isolated from North America, three groups were identified: a group consisting of strains from elm, oak, and plum; another group of strains from grapevine, almond, and ragweed; and strains from mulberry (Fig. 3).

All strains of Xylella fastidiosa produced an amplification product of the expected size (472 bp) after PCR was performed using primer pair 272-1-int and 272-2-int (Table 1). This amplification product was subjected to digestion with restriction endonucleases MspI, HaeIII, RseI, and CfoI. No digestion was observed with MspI, HaeIII, and RseI. However, there was a CfoI polymorphism between the citrus strains and strains from all other hosts. Interestingly, the coffee strains shared the RFLP pattern of the strains from all hosts except citrus (Fig. 4).

The 472-bp amplification product of primer pair 272-1-int and 272-2-int was cloned and sequenced from strains isolated from citrus, coffee, oak, mulberry, and grapevine. These strains represent the different groups revealed by REP-, ERIC-, and RAPDPCR. There were no nucleotide sequence differences among strains isolated from coffee, oak, mulberry, and grapevine. There were, however, limited sequence differences between strains isolated from citrus and strains isolated from the other hosts, consistent with the PCR-RFLP data.

\section{DISCUSSION}

REP- and ERIC-PCR $(11,29)$ have often been used to distinguish infra-specific variants within bacterial species. For example REP- and ERIC-PCR, originally developed for use with the Rhizobiaceae (11), distinguished four subgroups within Xanthomonas fragariae (22) and two major and two minor subgroups within Xanthomonas vesicatoria (18). In these cases, subgroups were identified within populations of a bacterial species pathogenic on a particular host (strawberry) or closely related hosts (tomato/pepper), respectively. In contrast, we were unable to identify any variants within a collection of 57 strains of Xylella fastidiosa isolated from diseased citrus in São Paulo State at various locations over several years (Fig. 1; Table 1). Thus, the degree of heterogeneity within the citrus strains of Xylella fastidiosa appears to be less than what was observed within Xanthomonas fragariae and Xanthomonas campestris pv. vesicatoria. These methods also failed to identify polymorphisms between strains isolated from diseased coffee and citrus strains from the same region. However, both REP- and ERIC-PCR revealed numerous polymorphisms between the citrus/coffee group and groups of strains isolated from grapevine, almond, and ragweed; mulberry; and oak, elm, and plum. These results are consistent with previous RFLP analyses of plasmid and genomic DNA $(5,6)$ and RAPD-PCR $(8,20)$ analysis of a more restricted group of strains.

RAPD-PCR performed on the same group of strains also failed to reveal any variation within the collection of citrus strains, consistent with the REP- and ERIC-PCR data. This analysis did however reveal clonal groups associated with other hosts of origin. These groups were entirely consistent with the groups defined by REP- and ERIC-PCR assays. However, two RAPD primers did reveal limited polymorphisms between the citrus and coffee strains (Fig. 2). The six RAPD primers used in this study were selected from a much larger set of primers that had been screened in Brazil 
for their ability to identify polymorphisms. The low level of heterogeneity observed in our collection of citrus strains is consistent with that observed by Rosato et al. (27) with a similar collection of strains from citrus. They observed no variation at all in RFLP profiles of $16 \mathrm{~S}$ rDNA fragments amplified by PCR, but did observe limited variation in RAPD-PCR product profiles with four of eight primers tested. The apparent difference in the RAPD-PCR results of the two studies could simply be due to the selection of primers.

Individual strains of Xylella fastidiosa are able to infect a wide range of plant species $(13,16,25)$. The clonal groups identified by REP-, ERIC-, and RAPD-PCR analyses of Xylella fastidiosa strains from various hosts in this study are also in agreement with the results of complete sequence analyses of the $16 \mathrm{~S}$ rDNA region of these strains (7). Based on the strains studied, the citrus and coffee strains are a natural group, as are the almond, grapevine, and ragweed strains and the elm, oak, and plum strains.

Our laboratory previously developed primer pairs useful for the detection of Xylella fastidiosa (21). Primer pair 272-1-int and 272-

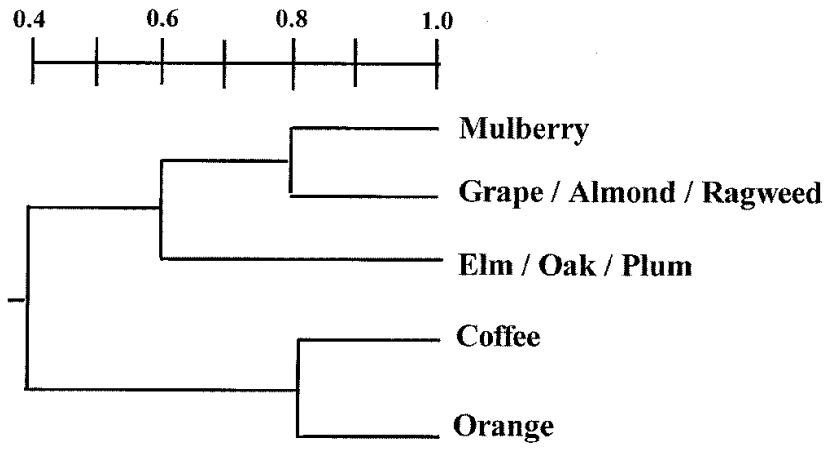

Fig. 3. Dendrogram based on a similarity matrix representing 56 strains of Xylella fastidiosa from various hosts. Branches are labeled by host of origin for the bacterial strains.
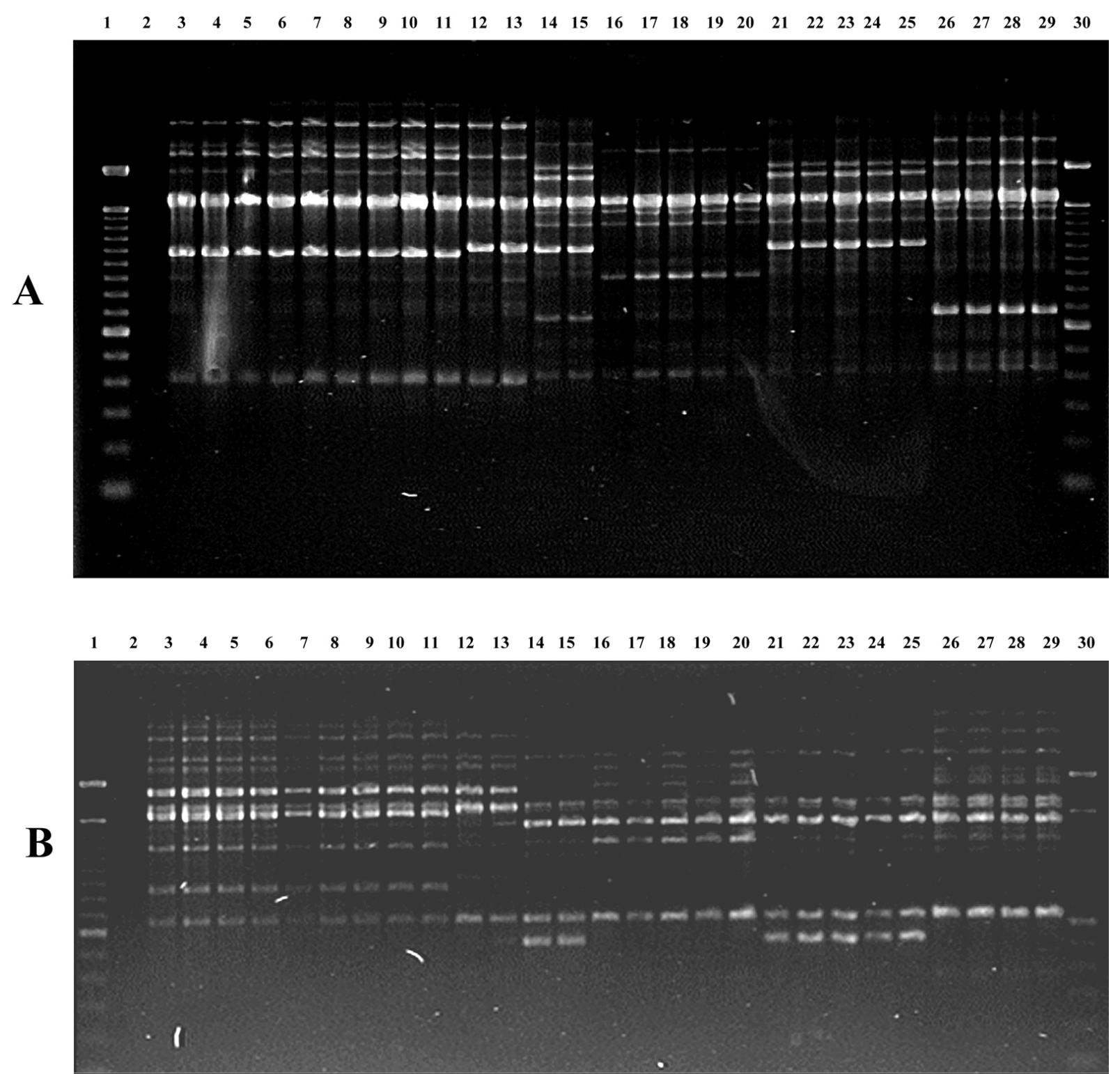

Fig. 2. Random amplified polymorphic DNA polymerase chain reaction (RAPD-PCR) analysis of strains representative strains of Xylella fastidiosa from citrus and other hosts. Products after amplification with primer A, AO9 and B, NO4 were separated by agarose gel electrophoresis. Lanes 3 to 11 , amplification products from citrus strains Col-7, Col-11, F-5, CVC-5, Funde-5, B-9, 3-B, CVC-L1, and PW; lanes 12 and 13, coffee strains Funde-4 and Caf2 20/11; lanes 14 and 15, grapevine and almond strains PCE-FG and ALS.BCG; lanes 16 to 20, strains ATCC 35873 (elm), ATCC 35874 (oak), ATCC 35871 (plum), Elm-J208, and Elm-1 (elm); lanes 21 to 25, strains ATCC 35881, 35879 and 35877 (grapevine), 35876 (ragweed), and 35870 (almond); and lanes 26 to 29, strains Mul-1, Mul-R, ATCC 35869, and 35868 (mulberry). Lanes 1 and 30, 100-bp DNA ladder; and lane 2, no template control for RAPD-PCR. 
2-int produced amplification products that were indistinguishable after gel electrophoresis from all strains tested. Nucleotide sequence analysis of representative strains did not reveal sufficient variation within this amplicon on which to base a differential PCR assay. However, digestion of the amplification product with $C f o$ I did reveal a polymorphism that can conveniently distinguish the coffee strains from the citrus strains (Fig. 4). Because this digestion can be performed directly in the PCR amplification mixture, it is very easy to implement. We anticipate that it will be very useful to determine if coffee and citrus strains are naturally present in any of a number of potential alternate plant hosts. This PCR-RFLP assay will also be useful to distinguish Xylella fastidiosa bacteria in sharpshooter insect vectors captured in the orchards and will be very useful in epidemiological studies of this complex pathosystem.

Our REP-, ERIC-, and RAPD-PCR analyses of this set of strains independently identified clusters of strains associated with the hosts from which the strains were isolated, as summarized in Figure 3. These differences are likely to be of taxonomic significance, particularly the low similarity $(S=0.45)$ between the strains from the United States and Brazil. In addition, in a separate study, a strain of Xylella fastidiosa isolated from plum in the United States grouped with strains isolated from grapevine in the United States, whereas a strain isolated from plum in Brazil grouped with citrus and coffee strains from Brazil (9). This is further evidence of a deep division within Xylella fastidiosa consistent with geography.

The presence of serious diseases of both coffee and citrus in São Paulo State raises very interesting questions. Although the citrus disease was the first to be described, the coffee disease is widespread and has apparently been present in São Paulo as an unrecognized problem for a long time. Indeed, because coffee culture long predates citriculture, it is possible that the citrus strains originated as a clonal variant of the coffee population. However, our failure to find a single coffee strain among the 57 citrus strains, or a citrus strain among the five coffee strains analyzed, is evidence that the

$\begin{array}{llllllllllllllll}1 & 2 & 3 & 4 & 5 & 6 & 7 & 8 & 9 & 10 & 11 & 12 & 13 & 14 & 15 & 16\end{array}$
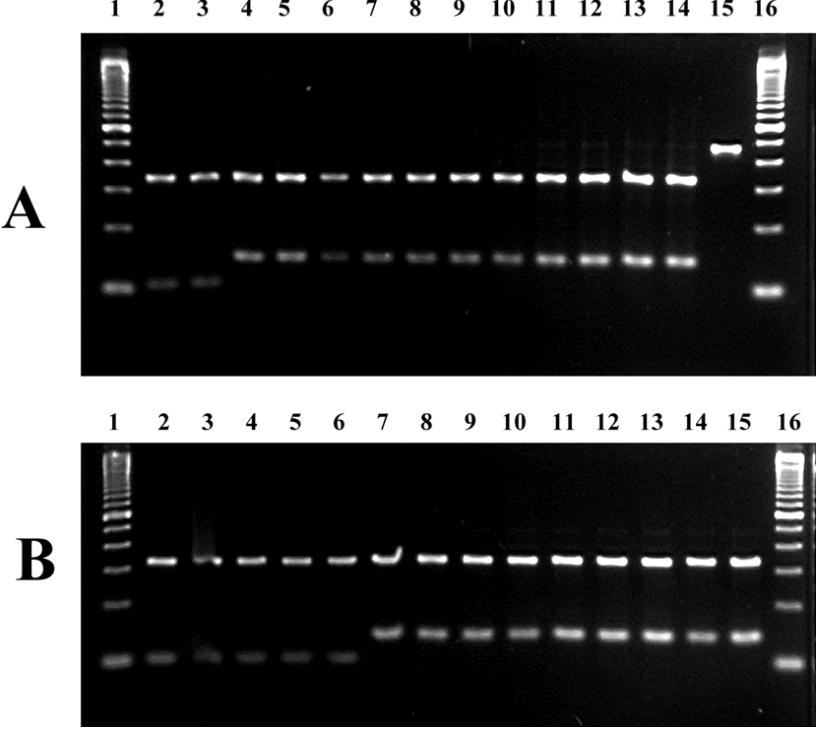

Fig. 4. Polymerase chain reaction restriction fragment length polymorphism analysis of representative strains of Xylella fastidiosa from citrus and other hosts. Products after amplification by primers 272-1-int and 272-2-int were digested with endonuclease $C f o \mathrm{I}$ and separated by electrophoresis. A, Lanes 2 to 14, strains CVC-5 and Funde-5 (citrus), Funde-4, Café 20/11 (coffee), ATCC 35881, ATCC 35879, ATCC 35877 (grapevine), ATCC 35876 (ragweed), ATCC 35870 (almond), MUL-1, MUL-R, ATCC 35869, and ATCC 35868 (mulberry); lane 15, undigested amplification product from strain CVC-5; and lanes 1 and 16, 100-bp ladder. B, Lanes 2 to 6, strains F-5, B-9, 3-B, CVC-L1, and PW (citrus); lanes 7 to 15, strains PCE-FG (grapevine), ALS.BCG (almond), ATCC 35873 (elm), ATCC 35874 (oak), ATCC 35871 (plum), ELM J208 and ELM-1 (elm), ATCC 35870 (almond), and ATCC 35868 (mulberry); and lanes 1 and 16, 100-bp ladder. strains are not pathologically interchangeable in nature, in spite of their close genetic relationship, and that the citrus strains are presumably better adapted for life in citrus plants than are the coffee strains. However, we have confirmed by inoculation that a citrus strain of Xylella fastidiosa can produce the full range of symptoms observed in plants suffering from Requiema do Café (17).

There has also been speculation that different strains of Xylella fastidiosa are present in diseased citrus in São Paulo State and that these strains could be responsible for differences in disease severity observed in the field (1). Our data are inconsistent with this idea, although they do not entirely rule it out. For example, we have observed several plasmid profiles in extracts from the citrus strains described here (data not shown), so these strains cannot be considered identical. The best explanation for the observed differences in disease severity is variation in local climate, particularly because citrus is produced without irrigation and there is a pronounced dry season in São Paulo State. This dry season is more severe in the northern areas of São Paulo State where the symptoms are more severe (1). Variations in soil structure or fertility and in the horticultural care given to the trees are also possible explanations for observed local variations in disease severity that do not require different strains of the pathogen to be present.

\section{ACKNOWLEDGMENTS}

We thank J. M. Wells (USDA-ARS) and D. Hopkins for providing bacterial strains, P. van Berkum (USDA-ARS) for assistance with the dendrogram, and C. Gouin for preparation of the figures.

\section{LITERATURE CITED}

1. Anonymous. 2000. CVC: Sintomas estão mais graves. Rev. Fundecitrus 99:8-9.

2. Brlansky, R. H., Timmer, L. W., French, W. J., and McCoy, R. E. 1983. Colonization of the sharpshooter vectors, Oncometopia nigricans and Homalodisca coagulata, by xylem-limited bacteria. Phytopathology 73: 530-535.

3. Chagas, C. M., Rosetti, V. A., and Beretta, M. J. G. 1992. Electron microscopy studies of a xylem limited bacterium in sweet orange affected with citrus variegated chlorosis disease in Brazil. J. Phytopathol. 134:306-312.

4. Chang, C. J., Garnier, M., Zreik, L., Rosetti, V., and Bové, J. M. 1993. Culture and serological detection of the xylem-limited bacterium causing citrus variegated chlorosis and its identification as a strain of Xylella fastidiosa. Curr. Microbiol. 27:137-142.

5. Chen, J., Chang, C. J., and Jarrett, R. L. 1992. Plasmids from Xylella fastidiosa strains. Can. J. Microbiol. 38:993-995.

6. Chen, J., Chang, C. J., Jarrett, R. L., and Gawel, N. 1992. Genetic variation among Xylella fastidiosa strains. Phytopathology 82:973-977.

7. Chen, J., Jarret, R. L., Qin, X., Hartung, J. S., Chang, C. J., and Hopkins, D. L. 2000. 16SrDNA analysis of Xylella fastidiosa. Syst. Appl. Microbiol. 23:349-354.

8. Chen, J. C., Lamikanra, O., Chang, C. J., and Hopkins, D. L. 1995. Randomly amplified polymorphic DNA analysis of Xylella fastidiosa Pierce's Disease and Oak scorch pathotypes. Appl. Environ. Microbiol. 61:1688-1690.

9. da Costa, P. I., Franco, C. F., Miranda, V. S., Teixeira, D. C., and Hartung, J. S. 2000. Strains of Xylella fastidiosa rapidly distinguished by arbitrarily primed-PCR. Curr. Microbiol. 40:279-282.

10. Davis, M. J., Purcell, A. H., and Thomson, S. V. 1976. Pierce's disease of grapevines: Isolation of the causal bacterium. Science 199:75-77.

11. de Bruijn, F. J. 1992. Use of repetitive (repetitive extragenic palindromic and enterobacterial repetitive intergenic consensus) sequences and the polymerase chain reaction to fingerprint the genomes of Rhizobium meliloti isolates and other soil bacteria. Appl. Environ. Microbiol. 58: 2180-2187.

12. de Lima, J. E. O., Miranda, V. S., Hartung, J. S., Brlansky, R. H., Coutinho, A., Roberto, S. R., and Carlos, E. F. 1998. Coffee leaf scorch bacterium: Axenic culture, pathogenicity, and comparison with Xylella fastidiosa of citrus. Plant Dis. 82:94-97.

13. Freitag, J. H. 1951. Host range of the Pierce's disease virus of grapes as determined by insect transmission. Phytopathology 41:920-934.

14. Hartung, J. S., Beretta, J., Brlansky, R. H., Spisso, J., and Lee, R. F. 1994. Citrus variegated chlorosis bacterium: Axenic culture, pathogenicity, and serological relationships with other strains of Xylella fastidiosa. 
Phytopathology 84:591-597.

15. Hopkins, D. L. 1989. Xylella fastidiosa: Xylem limited bacterial pathogen of plants. Annu. Rev. Phytopathol. 27:271-290.

16. Hopkins, D. L., and Adlerz, W. C. 1988. Natural hosts of Xylella fastidiosa in Florida. Plant Dis. 72:429-431.

17. Li, W.-B., Pria, W. D., Jr., Teixeira, D. C., Miranda, V. S., Ayres, A. J., Franco, C. F., Costa, M. G., He, C.-X., and Costa, P. I. 2001. Coffee leaf scorch caused by a strain of Xylella fastidiosa from citrus. Plant Dis. 85:501-505.

18. Louws, F. J., Fulbright, D. W., Stephens, C. T., and de Bruijn, F. J. 1995. Differentiation of genomic structure by rep-PCR fingerprinting to rapidly classify Xanthomonas campestris pv. vesicatoria. Phytopathology 85:528-536.

19. Mollenhauer, H. H., and Hopkins, D. L. 1976. Xylem morphology of Pierce's disease-infected grapevines with different levels of tolerance. Physiol. Plant Pathol. 9:95-100.

20. Pooler, M. R., and Hartung, J. S. 1995. Genetic relationships among strains of Xylella fastidiosa from RAPD-PCR data. Curr. Microbiol. 31:134-137.

21. Pooler, M. R., and Hartung, J. S. 1995. Specific PCR detection and identification of Xylella fastidiosa strains causing citrus variegated chlorosis. Curr. Microbiol. 31:377-381.

22. Pooler, M. R., Ritchie, D. F., and Hartung, J. S. 1996. Genetic relationships among strains of Xanthomonas fragariae based on random amplified polymorphic DNA PCR, repetitive extragenic palindromic PCR, and enterobacterial repetitive intergenic consensus PCR data and generation of multiplexed PCR primers useful for the identification of this phytopathogen. Appl. Environ. Microbiol. 62:3121-3127.
23. Purcell, A. H., Finlay, A. H., and McLean, D. L. 1979. Pierce's Disease bacterium: Mechanism of transmission by leafhopper vectors. Science 206:839-841.

24. Purcell, A. H., and Hopkins, D. L. 1996. Fastidious, xylem limited plant pathogens. Annu. Rev. Phytopathol. 34:131-151.

25. Raju, B. C., Goheen, A. C., and Frazier, N. W. 1983. Occurrence of Pierce's disease bacteria in plants and vectors in California. Phytopathology 73:1309-1313.

26. Roistacher, C. N. 1992. CVC: A warning and an appeal. Citrograph 77:17-18.

27. Rosato, Y. B., Neto, J. R., Miranda, V. S., Carlos, E. F., and Manfio, G. P. 1998. Diversity of a Xylella fastidiosa population isolated from Citrus sinensis affected by citrus variegated chlorosis in Brazil. Syst. Appl. Microbiol. 21:593-598.

28. Rosetti, V., Garnier, M., Bové, J. M., Beretta, M. J. G., Teixeira, A. R. R., Quaggio, J. A., and DeNegri, J. D. 1990. Presence de bacteries dans le xylem d'orangers atteint de chlorose variegee: Une nouvelle maladie des agrumes au Brazil. C.R. Acad. Sci. (Paris) 310:345-349.

29. Versalovic, J., Koeth, T., and Lupski, J. R. 1991. Distribution of repetitive DNA sequences in eubacteria and application to fingerprinting of bacterial genomes. Nucleic Acids Res. 19:6823-6831.

30. Wells, J. M., Raju, B. C., Hung, H.-Y., Weisburg, W., Mandelco-Paul, L., and Brenner, D. J. 1987. Xylella fastidiosa gen. Nov., sp. Nov.: Gramnegative, xylem-limited, fastidious plant bacteria related to Xanthomonas spp. Int. J. Syst. Bacteriol. 37:136-143.

31. Williams, J. G. K., Kubilik, A. R., Livak, K. J., Rafalski, J. A., and Tingey, S. V. 1991. DNA polymorphisms amplified by arbitrary primers are useful as genetic markers. Nucleic Acids Res. 18:6531-6535. 